患者と医療者に「優しい」環境をめざした無菌室の新設

高橋 彩 $^{1}$, 後藤清香 ${ }^{1}$, 加藤元博 ${ }^{2}$, 安部美樹子 ${ }^{1}$, 中村有希 ${ }^{1}$, 釷持 瞳 $^{1}$, 森田秀一 ${ }^{3}$, 松本有子 ${ }^{1}$, 松本公一 ${ }^{2}$

${ }^{1}$ 国立成育医療研究センター看護部

2 国立成育医療研究センター小児がんセンター

3 国立成育医療研究センター財務経理部

（日本造血細胞移植学会誌 $9(1): 46-49,2020$. ）

\section{緒言}

造血細胞移植を受ける患者は，感染症から身を守るため に，骨髄抑制から回復までの数週間を無菌室で過ごすこと になる ${ }^{1-3}$ 。この期間は, 無菌室内で複数の輸液ルートやモ ニター類が接続・装着され行動制限を強いられた状態で生 活しなくてはならない。一方で, 前処置や免疫反応による 臓器障害・粘膜障害などの苦痛な症状を伴いながらも, シャワー浴や口腔ケアなどの清潔行動を厳重に行う必要が ある。このことから，患者が体験する身体的・心理的苦痛 ははかり知れないものであるといえる。

そこで, 無菌室における療養環境を快適に整え, 患者の ストレスを緩和させて生活の質（Quality Of Life）を向上さ せることが求められる。これにより治療に対するアドヒア ランスが高まり，造血細胞移植の成功率の向上にもつなが る。

今回, 小児病院である当施設は, 移植件数の増加に伴い 無菌室を増床のため新設することとなった。快適な無菌室 にするべく，他施設の既存設備を訪問して，その長所を採 用し短所を改善する形での設計を行った。造血細胞移植治 療の環境整備に向けた貴重な情報となるため, 当施設が優 先した点や配慮した点について共有し, 患者と医療者の両 方にとって使いやすい「優しい」無菌室の要件について議 論する。

\section{方法}

医師・看護師および施設整備の専門職を中心とした多職 種チームを結成し，事前に 4 施設（大学病院 2 施設，小児 病院 2 施設）の無菌室を見学し，医療スタッフや患者・家 族から無菌室の使い心地を聴取した。得られた情報に加 え, 感染管理について院内の感染対策チームへのコンサル テーションを踏まえて設計を行った。

\section{結果}

主に以下の項目に配慮し, 個室 2 室および 4 人床 1 室の $36.59 \mathrm{~m}^{2}$ を改修し, 2 床の無菌室の設計を行った。その設計 図を Figure 1 および補助デー夕（Figure S1, S2）に示す。 無菌室増設に際し配慮した点について, Table 1 に示す。 HEPA フィルターを壁面に設置した場合，無菌度を維持す る層流を作るために部屋内に壁を作る必要があり，患者が 有効に使用できる面積が限られてしまう。そのため, HEPA フィルターを天井に設置することで， クラス 100 （ISO クラス 5）の空気清浄度を達成しつつょり広い面積を 確保した。廊下側と外向きに大きな空を設置し，室内の閉 鎖的な印象を軽減できるよう配慮した。

また，当施設既存の無菌室はドアが手動であり効率的な 陽圧管理を行うことが困難であった。そこでセンサーで開 閉可能な自動ドアとし，複数のドアが同時に開かないよう にした。

トイレやシャワー，手洗い台，収納棚などは患者や医療

Submitted May 14, 2019; Accepted September 1, 2019; Published online, January 15, 2020. (Handling Editor: Kenichiro Watanabe, Shizuoka Children's Hospital)

Key words: isolation room, equipment, newly establishment, environment

Correspondence: Motohiro Kato, Children's Cancer Center, National Center for Child Health and Development, 2-10-1 Okura, Setagaya-ku, Tokyo, 157-8535, Japan. E-mail: kato-mt@ncchd.go.jp dx.doi.org/10.7889/hct-19-005 (C) The Japan Society for Hematopoietic Cell Transplantation. 


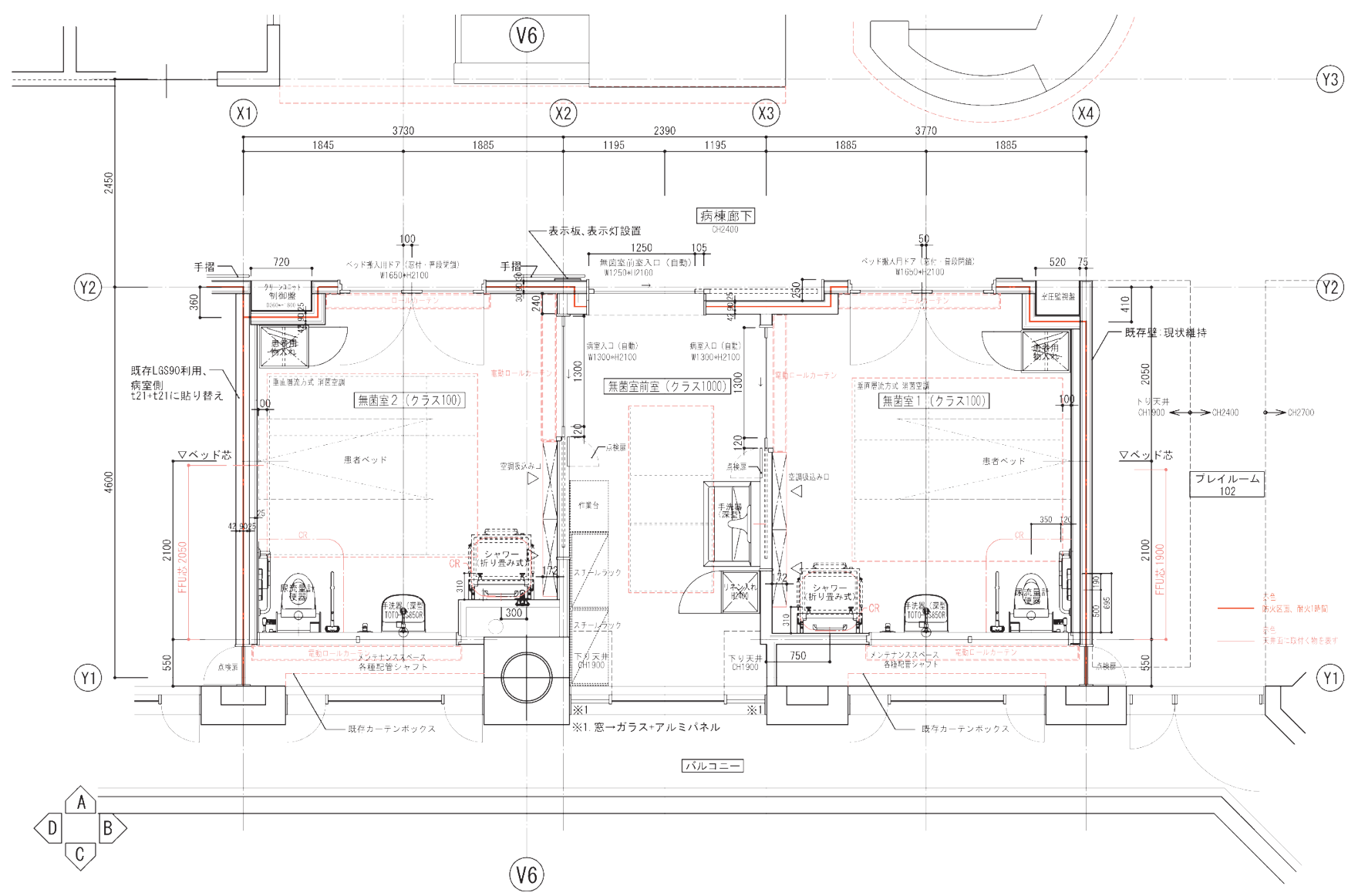

Figure 1. Design drawing of the newly established isolated rooms. Design drawing of a horizontal view. Two units are newly established. High-efficiency particulate air (HEPA) filters are located on the ceiling.

者の動線を配慮した配置とし，トイレは曝露予防の観点か ら自動で尿量測定が可能なタイプとした。また，水はねを 防止するため手洗い台のシンクを $38 \mathrm{~cm}$ と深くし, 手洗い 台やシャワーからのベッドやトイレの水はねがないことを 確認した。

43 インチの大画面テレビの設置により患者の娛楽への 満足度を高め, また, テレビ電話を設置することで, 感染 管理の事由で普段病棟内に立ち入れない 12 歳以下のきょ うだい児と顔を見ながら会話することが可能となった。

4 か月の準備期間，さらに 4 か月の工事期間を経て無菌 室 2 床が完成し, 稼働を開始した。2019年 3 月の時点で 11 件の移植を実施した。

\section{考察}

本稿では，当施設で新設した無菌室の設計に関する配慮 点について報告した。患者にとって無菌室での療養環境を 少しでも快適なものとし, 医療者にとっても利便性の高い 無菌室とするためには, 設備の充実が必要であり, それこ そが患者と医療者の双方にとって「優しい」無菌室の要件 と考えられる。しかし, 設計の段階では気づかず, 稼働し
た無菌室を使用してはじめてわかる改善点がしばしば経験 される。一方で, 無菌室の新設や改修は時間や費用などの 面から頻繁に行われるものではなく, さらに, 稼動後の根 本的な改築・改修は困難であることが多い。そのため, 貴 重な機会である無菌室の新設・改修にあたっては他施設で 稼働している既存設備の情報が貴重であるが，本報告で記 すような詳細な設計情報はほとんど公開されていない。

当施設に新設された無菌室は, 患者の利便性を高め, 医 療者にとっても使用しやすい環境を目指して設計した。し かし, このように様々な配慮点をふまえ設計した無菌室で も, 稼働後に明らかとなった改善が望まれる点があり，「二 重ドアである自動ドアの開閉に時間がかかる」,「入退室す る際，前室のガラス空に取り付けたロールカーテンが通行 の妨げになる」,「空調の吸い込み口にシャワーカーテンが 巻き达まれてしまい, シャワーの湯が床に飛び散りやす い」, 「遮音性が高いため輸液ポンプやモニターのアラーム 音が無菌室外に聞こえにくい」などの要素があげられた。 このような点の改善をさらに目指すことで，よりよい療養 環境を提供できると期待される。

無菌室の使い心地や改善が可能な箇所などの情報を施設 間で広く共有することで, 患者と医療者の双方に「優しい」 
Table1. A list of elaboration for newly established isolated rooms

\begin{tabular}{|c|c|c|}
\hline 項目 & 配慮点 & 目的·理由 \\
\hline \multirow{4}{*}{ 設計 } & HEPA フィルターを天井に配置する & $\begin{array}{l}\text { 壁面に設置すると, 無菌度を維持する層流を作るために部屋内に壁を作る必要 } \\
\text { があり, 患者が有効に使用できる面積が限られてしまうため。 }\end{array}$ \\
\hline & $\begin{array}{l}\text { 廊下直結のドア }(\mathrm{W} 1650 \text { mm×H2000 mm) } \\
\text { を設置する }\end{array}$ & $\begin{array}{l}\text { 緊急時に通常の個室のドアの広さでは搬出が困難であり, 患者の速やかな搬出 } \\
\text { を可能にするため。 }\end{array}$ \\
\hline & $\begin{array}{l}\text { Doors 出入口は自動ドアにし，開閉はセン } \\
\text { サー型のスイッチで行う }\end{array}$ & $\begin{array}{l}\text { 従来の自施設の無菌室や見学した施設では, 手洗い後の手でドアに触れる必要 } \\
\text { があったが, 別施設ではセンサー型のスイッチでの開閉を採用していた。扉に } \\
\text { 触れることがないようにすることで, 感染リスクを下げることが可能となる。 } \\
\text { また, 自動ドアにすることで, システム上複数のドアが同時に開かなくなり, } \\
\text { 厳密な陽圧管理が期待できる。 }\end{array}$ \\
\hline & $\begin{array}{l}\text { トイレとシャワーはベッドから最短距離に } \\
\text { 設置する }\end{array}$ & $\begin{array}{l}\text { 患者及び家族から, 体調不良時のトイレ・シャワーへの移動が負担になるとの } \\
\text { 意見があり, 移動距離を減らし, 倦怘感などの苦痛症状がある患者への負担を } \\
\text { 軽減するため。。 }\end{array}$ \\
\hline \multirow{3}{*}{ 設備 } & $\begin{array}{l}\text { シャワーの水圧を確保し, 直上に換気扇を } \\
\text { 設置する }\end{array}$ & $\begin{array}{l}\text { 見学した施設では, シャワーを設置したものの水圧が弱い, 湿気がこもるなど } \\
\text { の理由で使用頻度が低かった。患者が快適にシャワー浴を行うことができるよ } \\
\text { うにし, 効果的な換気によりカビの発生を予防するため。 }\end{array}$ \\
\hline & 自動で尿量測定が可能なトイレを導入する & $\begin{array}{l}\text { 正確な時刻・量のモニタリングが可能になり，かつ, 看護業務の負担軽減が期 } \\
\text { 待できる。 }\end{array}$ \\
\hline & 洗面台のシンクを深くする & $\begin{array}{l}\text { 見学した施設では, シンクの水はねがトイレに届いてしまう課題があり, 周囲 } \\
\text { への水はねを減らすため。 }\end{array}$ \\
\hline \multirow{2}{*}{ プライバシー } & $\begin{array}{l}\text { シャワーやトイレはカーテンで囲えるよう } \\
\text { にする }\end{array}$ & $\begin{array}{l}\text { 患者のプライバシーを保持するため。取り外し可能であり, 洗濯・交換により } \\
\text { 清潔を維持できるため。 }\end{array}$ \\
\hline & $\begin{array}{l}\text { ガラス空にはリモコンで操作できるロール } \\
\text { カーテンを設置する }\end{array}$ & $\begin{array}{l}\text { 倦怠感などにより離床困難であっても，患者自身が操作し，プライバシーを確 } \\
\text { 保することができる。 }\end{array}$ \\
\hline \multirow{4}{*}{ 景観，快適さ } & 廊下側にガラス空を設置する & 閉鎖的な印象を軽減し，患者の孤独感を軽減するため。 \\
\hline & $\begin{array}{l}\text { 外向きの空を大きくし }(W 2155 \mathrm{~mm} \times \\
\mathrm{H} 1130 \mathrm{~mm}), \text { 無菌室からの景観を確保する }\end{array}$ & $\begin{array}{l}\text { 空から外部が見えない無菌室で患者・家族の閉塞感が強いという意見があり， } \\
\text { 鎖的な印象を軽減し，患者の気分転換を図るため。 }\end{array}$ \\
\hline & 43 インチのテレビを設置する & 患者の娛楽への満足度を高めるため。 \\
\hline & テレビ電話を設置する & 病棟外の控室にいる面会者とコミュニケーションをとることができる。 \\
\hline
\end{tabular}

無菌室を整備できると考えられた。

本論文の補助データは日本造血細胞移植学会雑誌ウェブ サイト（https://www.jstage.jst.go.jp/article/hct/9/1/9_19005/_article/-char/ja/）を参照のこと。

本論文の概要は第 41 回日本造血細胞移植学会（2019年 3 月，大阪）にて発表した。

\section{謝辞}

無菌室の見学にご協力いただいた埼玉県立小児医療セン ター, 福島県立医科大学附属病院, 兵庫県立こども病院, 大阪 大学医学部附属病院の関係者に深謝いたします。

\section{利益相反の開示}

本論文に関し，開示すべき利益相反はない。

\section{文献}

1. 日本造血細胞移植学会. 造血細胞移植ガイドライン 造 血細胞移植後の感染管理. (https://www.jshct.com/ uploads/files/guideline/01_01_kansenkanri_ver04.pdf) Accessed 2019 March 15.

2. Passweg JR, Rowlings PA, Atkinson KA, et al. Influence of protective isolation on outcome of allogeneic bone marrow transplantation for leukemia. Bone Marrow Transplant. 1998; 21: $1231-1238$.

3. Hicheri Y, Einsele H, Martino R, et al. Environmental prevention of infection in stem cell transplant recipients: a survey of the Infectious Diseases Working Party of the European Group for Blood and Marrow Transplantation. Transpl Infect Dis. 2013; 15: 251-8. 


\title{
Newly construction of transplantation unit "kind-hearted" for patients and medical staffs
}

Aya Takahashi ${ }^{1}$, Sayaka Goto ${ }^{1}$, Motohiro Kato ${ }^{2}$, Mikiko Abe ${ }^{1}$, Yuki Nakamura ${ }^{1}$, Hitomi Kenmotsu ${ }^{1}$, Hidekazu Morita ${ }^{3}$, Yuko Matsumoto $^{1}$, Kimikazu Matsumoto ${ }^{2}$

${ }^{1}$ Department of Nursery, National Center for Child Health and Development, Tokyo, Japan

${ }^{2}$ Children's Cancer Center, National Center for Child Health and Development, Tokyo, Japan

${ }^{3}$ Department of Financial Affairs, National Center for Child Health and Development, Tokyo, Japan

\begin{abstract}
Hematopoietic stem cell transplantation (HCT) recipients should be accommodated for at least 2-3 weeks in a protective environment with high-efficiency particulate air (HEPA) filters. Amenity is very important for the recipients who have to overcome hard condition, and comfortability during transplantation highly depends on equipment of isolated rooms. To minimize the inconvenience of recipients, several elaborating equipment is required, however, detailed information for design drawing of isolated rooms is rarely available. Thus, to newly establish two units of isolated rooms in our hospital, we visited four institutions and conducted an interview with staffs and patients/parents, for satisfied/ dissatisfied points of the isolated rooms of each hospital. Based on the collected information, we established isolated rooms "kind-hearted" for both patients and medical staffs. We here share our design drawings for the isolated rooms with multiple ingenuity, which could contribute for basic information to newly establish isolation rooms. (Journal of Hematopoietic Cell Transplantation 9(1): 46-49, 2020.)
\end{abstract}

